\title{
LAW ON THE PROTECTION OF CHILDREN FROM DOMESTIC VIOLENCE ACCORDING TO LAW NO. 23 OF 2004
}

\author{
Dany Try Hutama Hutabarat ${ }^{1}$, Evi Yulyantika ${ }^{2}$, HikmaRotun ${ }^{3}$, Dewi Syamsiah ${ }^{4}$, Laila \\ Siti Nurhaliza ${ }^{5}$, Khairunnisa Nasution ${ }^{6}$, Ade Hastina Puri ${ }^{7}$, Sri Indah Lestari ${ }^{8}$, Nurainul \\ Mardiah $^{9}$, Mimi Arimbi ${ }^{10}$, Ahmad Fajar Mukti ${ }^{11}$ \\ $1-11$ \\ Universitas Asahan \\ E-mail: ${ }^{1)}$ danytryhutamahutabarat@gmail.com, ${ }^{2)}$ eviiylyntka20@gmail.com, \\ ${ }^{3)}$ hikmahhrtn@gmail.com, ${ }^{4}$ syamsiahdewii@gmail.com, ${ }^{5)}$ lailasitinurhalizah31@gmail.com, \\ ${ }^{6}$ khairunnisa69007@gmail.com, 7) adehastinapurisinurat@gmail.com, \\ ${ }^{8)}$ indahlestariv0308@gmail.com, ${ }^{9)}$ ainulpanjaitan133@gmail.com, \\ 10)mimivivo89@gmail.com, ${ }^{11)}$ ahmadfajarmukti11@gmail.com
}

\begin{abstract}
The violence in the family is frequently difficult to detect, and the public paradigm continues to assume that something happens in the family is private. The presence of Laws number 23 of 2004 on the elimination of domestic violence is expected to protect state citizens from unsettling senses and forms of violence, but the number of incidents of domestic violence in everyday life instantly increases. As the Writer will examine the function of Laws number 23 of 2004 prohibiting domestic violence in providing protections for state citizens, particularly those who are victims of domestic abuse. By focusing on the following questions: Is it sufficient to safeguard state citizens who are victims of domestic violence? and What should be done to reduce the number of domestic violence cases in Indonesia? The conclusion drawn by the author is that Laws number 23 of 2004 prohibiting domestic violence have been sufficient to protect victims and offer an elementary level of protection to law enforcement. However, its implementation must be coherent and systematic, not only with the country according to its instruments of power, but also with the population that supports the eradication of domestic violence.
\end{abstract}

Keywords: Domestic Violence Protection Law, Domestic Violence, Law Enforcement

\section{INTRODUCTION}

The family is the smallest unit of society, where each member of the family grows and develops socially, and where the formation of one's character is heavily influenced by one's upbringing and family background. Family members are typically comprised of a father, mother, and children, all of whom have deep emotional and social bonds with one another and exert influence over one another. Conflicts and differences of view are typical in a family, but what is being discussed is how to respond to or respond to these differences of opinion in a constructive manner.

According to the law, family difficulties are private matters that cannot be arbitrarily interfered with by the government or others. When viewed in light of the social paradigm that the internal difficulties of the family are internal problems where there is frequently violence. 
Indonesia has enacted Law Number 23 of 2004 concerning the Elimination of Domestic Violence, which is a significant progress for the state in providing protection and guarantees of human rights for individual citizens, especially as family members.

Specifically, it is believed that by enacting Law Number 23 of 2004 about the Elimination of Domestic Violence, citizens will be protected against insecurity as well as other forms of violence that are not in accordance with the Pancasila and 1945 Constitutional ideals. As a consequence, citizens are protected or released from acts or threats of acts of violence, torture, or other treatment that brings down human dignity and standing, which is very likely to occur inside the family environment (household) (Pandiangan, 2017).

Based on data from the National Commission on Human Rights of Women (Komnas HAM Perempuan, 2018) In 2018, there were a total of 348,446 cases of violence against women that were reported and handled. Of the total number of cases, violence in the private/personal sphere was recorded at the highest at $71 \%$ or around 9,609 cases. From this data, it is clear that in Indonesia cases of domestic violence are still very high despite the protection provided by Law Number 23 of 2004 concerning the Elimination of Domestic Violence. Hence, the author will try to describe about the role of Law Number 23 of 2004 concerning the Elimination of Domestic Violence in providing guarantees of protection for citizens, especially those who have become victims of domestic violence.

\section{RESEARCH METHODS}

The approach method used is a normative juridical approach or a statutory approach. As a specification of the research is descriptive analytical juridical research, with data sources in the form of primary, secondary and tertiary legal materials, as well as supported by primary data, and analyzed qualitatively juridically.

This type of research is socio-juridical or includes descriptive research with a nondoctrinal approach, which views law as a socio-empirical phenomenon observed in experience. For this reason, it is not only studied from the normative aspect, but also the law as in reality. Until now, the methods of overcoming violations of child protection are mostly still at the level of assistance, both children who are in conflict with the law or children who are victims.

\section{FINDINGS AND DISCUSSION}

Based on the provisions of Article 1 point 1 of Law no. 23 of 2004 concerning the Elimination of Domestic Violence, what is meant by the definition of domestic violence, namely: any act against a person, especially a woman, which results in physical, sexual, psychological misery or suffering, or neglect of the household including threats to commit such acts, coercion or deprivation of liberty against the law within the scope of the household.

When the definition of domestic abuse is studied in light of the wording of Law Number 23 of 2004, it becomes clear that the victims are primarily women. Because women's positions are often weak physically and socially when coupled with the patriarchal culture prevalent in many places of Indonesia. Women are frequently the targets of violence, threats of violence, sexual, psychological, and other forms of abuse. Indeed, not only women, but 


\section{POLICY, LAW, NOTARY AND REGULATORY ISSUES (POLRI) \\ VOLUME 1 ISSUE 1 (2022)}

also children, occupy a weak and vulnerable position within the family. Where youngsters are under parental supervision, and so forth.

Women and children are victims of various forms of violence they experience. According to the provisions of Article 2 of Law Number 23 of 2004, the scope of this law is:(Saraswati, 2015)

1) Husband, wife, and children;

2) People who have family relations with their husbands, wives and children, because of blood relations, marriage, breastfeeding, parenting, and guardianship, who live in the household; and/or

3) People who work to help the household and stay in the household.

The state, government, society, family, and parents are all responsible for protecting children in the areas of religious life, education, health, and social. There are many parts of life in which children play a role that must be safeguarded, and their lives are no different from those of other people.

The protection of children is crucial because children are the successors to the life of the nation and the state, and if they have reached a mature stage in their physical, mental, and social development, it is time for them to take over for the preceding generation of leaders.

The achievement of legal certainty for children is one kind of child protection. Legal clarity, according to Arif Gosita, serves to avoid discrimination against children, which will inevitably have a detrimental influence on the child himself or herself (Gosita, 2004).

Child protection is a critical issue that should be sought from things that grow in people's life, such as prostitution, which is inextricably linked to the economic component. Another issue that frequently affects children is the violence they encounter at home and at school as a result of poverty, societal norms, religion, and rituals. Additionally, as technological advancements continue, children are frequently implicated in criminal activities such as child trafficking and child pornography.

The nature of child protection itself can be divided into two parts according to the author, both of which are the core elements in child protection. The two parts that the author means are:

1) Juridical child protection includes:

a) Protection in the field of public law; and

b) Protection in the field of civil law.

2) Non-juridical child protection includes:

a) Social protection,

b) protection in the health sector,

c) Protection in the field of education.

Indonesia has ratified the Convention on the Rights of the Child and its protocol, through Presidential Decree no. 36 of 1990 and Law no. 5 of 1998 as ratification of the Convention against Torture and other cruel treatment or punishment. inhumane which demeans human dignity. Therefore, it is legally bound to implement the convention and make it part of the applicable laws and regulations. In Indonesia itself, regulations regarding child protection have been issued in accordance with the needs of the people in Indonesia, the role of the international community in supervising the fulfillment of children's rights based on the 
Convention of The Right of a Child where this also has a positive effect on the development of child protection in Indonesia (Salam et al., 2021).

Law Number 35 of 2014 concerning child protection emphasizes that the organizers of child protection are parents, family, government and the state, the first burden in implementing child protection falls on the parents, but in this modern era, most parents are busy with their work and start ignore his son.

Crimes against children each year increase very rapidly, based on the results of monitoring by KPAI (Indonesian Child Protection Commission) from 2011 to 2014 before the enactment of Law No. 35 of 2014 concerning Child Protection, there were 2178 cases of violence in 2011, while in 2012 there were 3512 cases, in 2013 there were 4311 cases and in 2014 there were 5066 cases (Citradewi et al., 2022). The number is children who are victims, while children in conflict with the law from 2011 to 2015 amounted to 6006 cases, followed by 3160 cases of caregiving, 1764 cases of education, 1366 cases of health and drugs and 1032 cases of pornography and cybercrime (Mamesah et al., 2018).

According to the most recent data available from the Indonesian Child Protection Commission, the commission received 3,851 public complaints in 2016 alleging infringement of children's rights. This demonstrates that children who live in tough circumstances either become victims of violence or are in dispute with the law have not developed properly.

Apart from the facts mentioned above, another matter of concern is the exploitation of children in the sexual sector. The government admits that there is no accurate data, but it is estimated that from all cases of sexual exploitation around $60 \%$ of the victims are children. While the majority of the $60 \%$ of the victims were women and some were boys.

Women and children are victims of various forms of violence they experience. According to the provisions of Article 2 of Law Number 23 of 2004, the scope of this law is:

1) Husband, wife, and children;

2) People who have family relations with their husbands, wives and children, because of blood relations, marriage, breastfeeding, parenting, and guardianship, who live in the household; and/or

3) People who work to help the household and stay in the household.

Child protection is endeavored by everyone, both parents, family, community, government and state. Article 20 of Law Number 35 of 2014 stipulates: "The State, Government, Regional Government, Community, Family, and Parents or Guardians are obliged and responsible for the implementation of Child Protection."

Therefore, the one who seeks child protection is every member of the community according to his ability with various kinds of efforts in certain situations and conditions (Maemunah, 2019). Every citizen is responsible for the implementation of child protection for the welfare of the child itself.

Children's happiness is shared happiness, protected happiness is protective happiness. There is no anxiety in children, because child protection is carried out properly and children become prosperous (Sukadi, 2013). Child welfare has a positive influence on parents, family, community, government, and the state. Child protection benefits children and their parents, families, communities, governments, and the state. 


\section{POLICY, LAW, NOTARY AND REGULATORY ISSUES (POLRI) \\ VOLUME 1 ISSUE 1 (2022)}

Coordination of cooperation in child protection activities needs to be carried out in order to prevent an imbalance in child protection activities as a whole (Said, 2018). The obligations and responsibilities of the State and Government in child protection efforts are regulated in Law Number 35 of 2014 namely:

a. The State, Government and Regional Governments are obliged and responsible for respecting the fulfillment of children's rights without distinction of ethnicity, religion, race, class, gender, ethnicity, culture and language, legal status, birth order, and physical and/or mental condition (Article 21);

b. The State, Government and Regional Governments are obliged and responsible for providing support for facilities, infrastructure, and the availability of human resources in the implementation of Child Protection (Article 22);

c. The State, Government and Regional Governments guarantee the protection, maintenance of welfare and supervise the implementation of Child protection by taking into account the rights and obligations of Parents, Guardians, or other people who are legally responsible for the Child (Article 23);

d. The State, Government, and Local Government guarantee the Child to exercise his right to express his opinion according to the child's age and level of intelligence (Article 24).

e. Community obligations and responsibilities for Child Protection involve community organizations, academics, and child observers, carried out through community role activities in the implementation of Child Protection (Article 25).

Efforts to protect children are motivated not only by a desire to provide them with care and financial security, but also by a feeling of "fairness" in dealing with the fate of these vulnerable individuals. Children's physical and spiritual well-being and even their lives are at risk if they do not receive the care and attention they require. A sense of justice provides a bond in the form of a moral obligation to meet various needs that, if not met, threaten their physical and spiritual well-being and even their lives.

\section{CONCLUSION}

The establishment of Law No. 23 of 2004 on the Elimination of Domestic Violence has been significant to provide protection for domestic violence victims and law enforcement for domestic violence perpetrators. Only at the implementation level must comprehensive and synergistic efforts be made by law enforcement agencies, specifically the police, prosecutors, courts, and advocates, to reduce the occurrence or recurrence of acts or cases of domestic violence. Systematic and comprehensive efforts are required, both from the State through its institutions and tools of power, and from the community that supports efforts to eliminate domestic violence. It is vital for law enforcement to collaborate in informing the community in order to prevent violence in the home, and it is necessary to raise awareness in the community in order to develop a family in carrying out everyday activities.

Legal protection for children is essentially an effort made by parents, government and society to fulfill and guarantee all children's rights that have been guaranteed in the convention on children's rights and Law Number 35 of 2014 concerning Child Protection. Legal protection for children in the perspective of human rights is not implemented because 
the government has not carried out its obligations in fulfilling children's rights so that there are still violations of the law against children.

\section{REFERENCES}

Citradewi, D. M., Dwijayanto, S. K., \& Harjo, M. (2022). Legalitas Penjaminan Anak Sebagai Objek Jaminan Hutang Dari Perspektif Hukum Dan Agama. Jurnal Education And Development, 10(1), 158-166.

Gosita, A. (2004). Masalah perlindungan anak. Bhuana Ilmu Populer.

Komnas HAM Perempuan. (2018). Lembar Fakta dan Poin Kunci Catatan Tahunan (CATAHU) Komnas Perempuan Tahun 2018 Tergerusnya Ruang Aman Perempuan dalam Pusaran Politik Populisme.

Maemunah, M. (2019). Perlindungan Hukum Anak Jalanan Dalam Konsep Ham Pasca Reformasi. Jatiswara, 34(2), 193-211.

Mamesah, A., Rompas, S., \& Katuuk, M. (2018). Hubungan verbal abuse orang tua dengan perkembangan kognitif pada anak usia sekolah di sd inpres tempok kecamatan tompaso. JURNAL KEPERAWATAN, 6(2).

Pandiangan, L. E. A. M. (2017). Perlindungan Hukum Dari Kekerasan Dalam Rumah Tangga Menurut UU Nomor 23 Tahun 2004. To-Ra, 3(2), 607-612.

Said, M. F. (2018). Perlindungan Hukum Terhadap Anak Dalam Perspektif Hak Asasi Manusia. JCH (Jurnal Cendekia Hukum), 4(1), 141-152.

Salam, S. N., Wagiman, H., Akib, I., Sugiati, A., \& Situmorang, B. H. L. (2021). Perlindungan Hukum Terhadap Hak Anak Menurut Uu Nomor Nomor 35 Tahun 2014 Tentang Perlindungan Anak. Jtcsa Adpertisi Journal, 2(2), 32-37.

Saraswati, R. (2015). Hukum perlindungan anak di Indonesia (Issue 2). PT. Citra Aditya Bakti.

Sukadi, I. (2013). Tanggung Jawab Negara Terhadap Anak Terlantar Dalam Operasionalisasi Pemerintah Di Bidang Perlindungan Hak Anak. Journal de Jure, 5(2). 